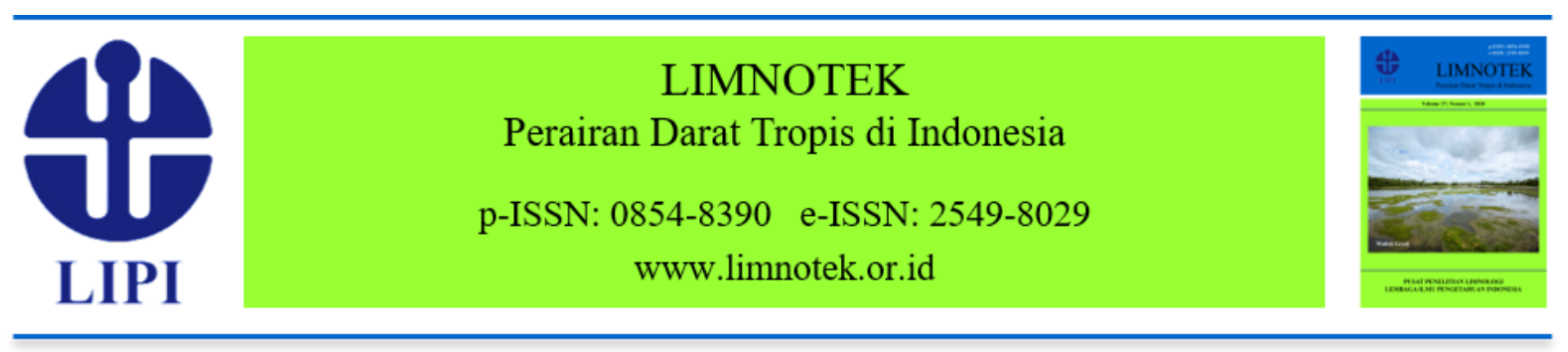

\title{
Pengaruh Pemanfaatan Lahan terhadap Kualitas Air Sungai Percut dengan Metode Indeks Pencemaran (IP)
}

\author{
Machairiyah $^{1}$, Zulkifli Nasution $^{2}$, Bejo Slamet $^{3}$ \\ ${ }^{1}$ Sekolah Pascasarjana Pengelolaan Sumber Daya Alam dan Lingkungan, \\ Universitas Sumatera Utara, Medan \\ ${ }^{2}$ Fakultas Pertanian, Universitas Sumatera Utara, Medan \\ ${ }^{3}$ Fakultas Kehutanan, Universitas Sumatera Utara, Medan \\ Email: machairiyah@gmail.com
}

Diajukan 27 Januari 2020. Ditelaah 16 Mei 2020. Disetujui 14 Juni 2020.

\begin{abstract}
Abstrak
Sungai Percut mengalir dari hulu Sibolangit dan melintasi Kota Medan menuju daerah hilir di Kecamatan Percut Sei Tuan. Sungai ini menjadi tempat pembuangan limbah dan sampah yang berdampak pada kualitas air. Penelitian ini menganalisis status mutu air untuk mengetahui pengaruh pemanfaatan lahan terhadap kondisi mutu air Sungai Percut. Pengambilan sampel air dilakukan di lima titik sampling dari hulu sampai ke hilir. Parameter yang dianalisis yaitu parameter fisika, kimia, dan biologi dengan metode Indeks Pencemaran (IP) sesuai dengan Keputusan Menteri Negara Lingkungan Hidup Nomor 115 Tahun 2003. Hasil penelitian menunjukkan bahwa status mutu air Sungai Percut tercemar ringan. Nilai IP tertinggi diperoleh di Titik 1 (daerah hulu) sebesar 3,55 akibat longsor yang terjadi sebulan sebelum penelitian dan hujan pada hari pengambilan sampel, diikuti dengan nilai IP sebesar 3,06 di Titik 5 (daerah hilir) akibat pemanfaatan lahan yang beragam di sekitar titik sampling seperti permukiman, pertanian, perkebunan, pertambakan, dan akumulasi beban pencemar yang berasal dari hulu. Nilai IP terendah sebesar 2,21 ditemukan di Titik 4 yang merupakan daerah permukiman. Nilai BOD semakin tinggi ke daerah hilir dengan nilai tertinggi $4,05 \mathrm{mg} / \mathrm{L}$ yang melebihi baku mutu ditemukan di Titik 5, mengindikasikan pencemaran Sungai Percut disebabkan oleh limbah organik. Pemantauan kualitas air dan pengawasan penting dilakukan untuk mengetahui strategi pengelolaan dan pengendalian pencemaran yang tepat agar status mutu air Sungai Percut dapat dipertahankan sesuai peruntukannya. Selain itu, kondisi hutan di daerah hulu harus tetap dipertahankan dan pemanfaatan lahan pertanian dan permukiman harus dikontrol dengan tidak membuang limbah ke sungai.
\end{abstract}

Kata kunci: kualitas air, pemanfaatan lahan, indeks pencemaran, Sungai Percut 


\begin{abstract}
Effect of Land Use on Percut River Water Quality with the Pollution Index (IP) Method. Percut River flows from the upstream Sibolangit and crosses Medan City to the downstream area in Percut Sei Tuan District. This river becomes waste and rubbish disposal sites which have an impact on water quality. This study analyzes the status of water quality to determine the effect of land use on the water quality condition of Percut River. Water sampling was carried out at five sampling sites from the upstream to the downstream. The parameters analyzed were physical, chemical, and biological parameters using the Pollution Index (IP) method in accordance with the Decree of the State Minister for the Environment No. 115 of 2003. The results showed that the water quality status of Percut River was lightly polluted. The highest IP value was obtained at Site 1 (upstream area) of 3.55 due to landslides that occurred a month before the study and rain on the day of sampling, followed by IP value of 3.06 at Site 5 (downstream) due to various land uses around the sampling sites such as settlements, agriculture, plantations, aquaculture, and accumulation of pollutant loads originating from the upstream. The lowest IP value of 2.21 was found at Site 4 which is a residential area. The BOD value was higher to the downstream area with the highest value of $4.05 \mathrm{mg} / \mathrm{L}$ at Site 5 which exceeded the quality standard, indicating that Percut River pollution was caused by organic waste. Water quality monitoring and supervision are important to know the proper pollution management and control strategies so that the water quality status of Percut River can be maintained as intended. In addition, the condition of forests in the upstream areas must be maintained and the use of agricultural land and settlements must be controlled by not dumping waste into the river.
\end{abstract}

Keywords: water quality, land use, pollution index, Percut River

\section{Pendahuluan}

Sungai Percut mengalir dari daerah hulu, yaitu Kecamatan Sibolangit di Kabupaten Karo, melintasi Kota Medan dan menuju daerah hilir di Kecamatan Percut Sei Tuan, Kabupaten Deli Serdang. Secara administratif, Sungai Percut mengalir di tiga kabupaten dan kota di Provinsi Sumatra Utara, yaitu Kabupaten Karo, Kabupaten Deli Serdang, dan Kota Medan. Secara geografis, sungai ini berada di $3^{\circ} 10^{\prime} 40,87^{\prime \prime}$ sampai $3^{\circ} 46^{\prime} 20,77^{\prime \prime}$ LU dan 98 $32^{\prime} 01,20^{\prime \prime}$ sampai $98^{\circ} 48^{\prime} 02,88^{\prime \prime}$ BT. Sungai Percut dimanfaatkan untuk banyak hal bagi masyarakat di sekitarnya, antara lain sumber air bersih, irigasi untuk pertanian, perikanan tambak, bahkan tempat pembuangan limbah domestik dan industri. Kualitas air Sungai Percut dipengaruhi oleh aktivitas manusia yang memanfaatkan lahan di sekitar sungai. Material pencemar yang masuk ke dalam aliran sungai menyebabkan penurunan kualitas air sungai (Ali et al., 2013). Beban pencemar yang masuk tidak boleh melebihi kemampuan sungai melakukan self purification (Suwari, 2010). Jika lebih, maka sungai akan tercemar dan tidak sesuai dengan peruntukannya. Bagian hilir Sungai Percut mengalami dampak terbesar dari pencemaran limbah organik yang terjadi, yang ditandai dengan nilai BOD yang tinggi.

Berdasarkan sumbernya, pencemaran dibedakan menjadi Point Source (PS) yaitu jika sumber pencemaran berasal dari satu lokasi atau titik tertentu dan Nonpoint Source (NPS) yaitu jika sumber pencemaran berasal dari banyak lokasi (Marlena, 2012). PS bersifat lokal dan volume pencemar relatif tetap misalnya saluran limbah industri dan cerobong asap pabrik, sedangkan pencemaran NPS berasal dari banyak sumber yang menyebar berupa limpasan tanah, drainase, curah hujan, dan modifikasi hidrologi. NPS mengalir dan bergerak terus membawa polutan ke sungai, danau, lahan 
basah, perairan pantai, dan air tanah (EPA, 2018).

Dalam penelitian ini, status mutu air Sungai Percut dianalisis dengan metode Indeks Pencemaran (IP) (Saraswati et al., 2014) dan dirujuk menurut Keputusan Menteri Lingkungan Hidup Nomor 115 Tahun 2003 tentang Pedoman Penentuan Status Mutu Air. Metode ini dapat menganalisis data tunggal, sehingga efisien dalam waktu dan biaya dalam penentuan status mutu air, sedangkan metode lain seperti metode Storet membutuhkan times series data. Metode Indeks Pencemaran dapat mengetahui parameter-parameter yang menjadi penyebab status mutu air yang rendah, sehingga pengelolaan yang tepat dapat dilakukan. Tujuan penelitian ini adalah untuk mengetahui kualitas air Sungai Percut agar sesuai dengan peruntukannya dan manfaatnya sebagai sumber informasi dalam melakukan pengawasan status mutu air Sungai Percut.

\section{Bahan dan Metode}

Penelitian dilaksanakan pada bulan Mei 2019 dan pengambilan sampel air dilakukan di lima titik sampling dari hulu sampai hilir Sungai Percut (Gambar 1 dan Tabel 1). Setiap titik sampling mewakili pemanfaatan lahan yang berbeda di setiap kawasan.

Titik sampling ditentukan berdasarkan analisis spasial (Sholikhah et al., 2017) dengan menggabungkan peta tutupan lahan dan peta Daerah Aliran Sungai (DAS) Percut. Penentuan titik sampling untuk pengambilan sampel air dilakukan dengan metode Purposive Sampling dan mewakili pemanfaatan lahan di kawasan tersebut. Sampel air diambil menggunakan metode Grab dengan dua kali pengulangan.

Parameter yang dianalisis adalah parameter fisika, kimia, dan biologi. Sampel air dianalisis di Laboratorium Shafeera Enviro, Medan untuk parameter fisika dan

Tabel 1. Titik pengambilan sampel air

\begin{tabular}{|c|c|}
\hline Titik sampling & Keterangan \\
\hline $\begin{array}{l}\text { Titik 1 Jembatan Bukum Sibolangit } \\
\text { (3¹4'58,2” LU dan } 98^{\circ} 33^{\prime} 54,99^{\prime} \text { BT) }\end{array}$ & $\begin{array}{l}\text { Daerah hulu, merupakan kawasan } \\
\text { hutan }\end{array}$ \\
\hline $\begin{array}{l}\text { Titik } 2 \text { Jembatan Sarilabajahe } \\
\text { Namorambe-Sibiru-biru } \\
\left(3^{\circ} 21^{\prime} 47,4^{\prime \prime} \text { LU dan } 98^{\circ} 40^{\prime} 2,6^{\prime \prime} \text { BT) }\right.\end{array}$ & $\begin{array}{l}\text { Pertanian sawah, permukiman, dan } \\
\text { kawasan wisata Sungai Sibiru-biru }\end{array}$ \\
\hline $\begin{array}{l}\text { Titik } 3 \text { Jembatan Amplas } \\
\left(3^{\circ} 32^{\prime} 20,2^{\prime \prime} \text { LU dan } 98^{\circ} 42^{\prime} 48,0^{\prime \prime} \text { BT) }\right.\end{array}$ & $\begin{array}{l}\text { Permukiman, perkotaan, pertanian, } \\
\text { dan industri }\end{array}$ \\
\hline $\begin{array}{l}\text { Titik } 4 \text { Jembatan Tembung } \\
\text { (3³5’46,9” LU dan } 98^{\circ} 44^{\prime} 42,33^{\prime} \text { BT) }\end{array}$ & Permukiman \\
\hline $\begin{array}{l}\text { Titik } 5 \text { Jembatan Paluh Merbau-Tanjung Rejo } \\
\left(3^{\circ} 43^{\prime} 15,2^{\prime \prime} \text { LU dan } 98^{\circ} 44^{\prime} 57,4^{\prime \prime} \text { BT }\right)\end{array}$ & $\begin{array}{l}\text { Daerah hilir, permukiman, tambak, } \\
\text { rawa, dan sawah }\end{array}$ \\
\hline
\end{tabular}




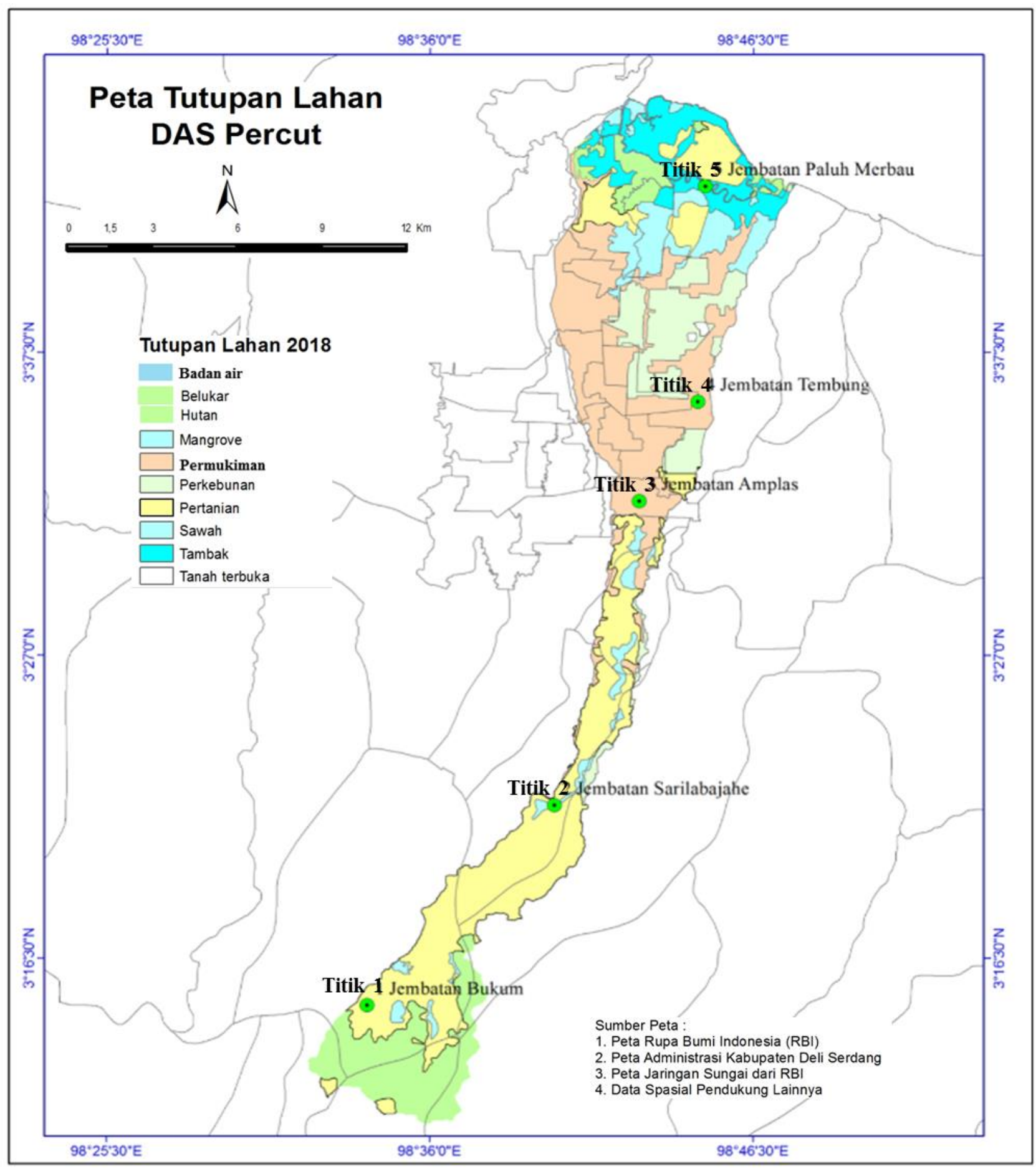

Gambar 1. Lokasi penelitian di Sungai Percut

kimia, sedangkan parameter biologi dianalisis di Laboratoriun Balai Teknik Kesehatan Lingkungan dan Pengendalian Penyakit (BTKLPP) Kelas I, Medan.

Parameter fisika meliputi kekeruhan, Total Suspended Solids (TSS), dan suhu air. Parameter kimia terdiri dari $\mathrm{pH}$, Dissolved
Oxygen (DO), Biochemical Oxygen Demand (BOD), Chemical Oxygen Demand (COD), konsentrasi nitrat, nitrit, amonia, dan fosfat. Parameter DO suatu perairan dalam kondisi sehat terlihat dari jumlah oksigen terlarut yang tinggi dalam perairan tersebut (Priyambada \& Suprapto, 2008), sedangkan 
untuk parameter BOD, semakin tinggi nilainya maka kondisi perairan semakin tercemar. Parameter biologi diukur dengan keberadaan bakteri coliform golongan fekal (di antaranya Escherichia coli) dalam perairan yang berasal dari kotoran manusia dan hewan, serta golongan nonfekal (di antaranya Aerobacter dan Klebsiella) yang berasal dari hewan atau tanaman yang sudah mati (Puspitasari et al., 2017). Keberadaan bakteri digunakan sebagai indikator tingkat higienisitas suatu perairan (du Plessis et al., 2014). Semua parameter yang diuji diperlihatkan dalam Tabel 2.

Status mutu air dianalisis dengan metode IP berdasarkan Keputusan Menteri Negara Lingkungan Hidup Nomor 115 Tahun 2003 dengan persamaan:

$$
I_{j}=\sqrt{\frac{\left(\frac{C_{i}}{L_{i j}}\right)_{M}^{2}+\left(\frac{C_{i}}{L_{i j}}\right)_{R}^{2}}{2}}
$$

Keterangan:

$\mathrm{IP}_{\mathrm{j}}$ : Indeks Pencemaran

$\mathrm{C}_{\mathrm{i}}$ : Konsentrasi parameter kualitas air i

$\mathrm{L}_{\mathrm{ij}}$ : Konsentrasi parameter kualitas air i yang tercantum dalam baku peruntukan air $\mathrm{j}$

$\mathrm{M}$ : Nilai maksimum

$\mathrm{R}$ : Nilai rata-rata

Metode Indeks Pencemaran ditentukan dari resultan nilai maksimum dan nilai rerata rasio konsentrasi per parameter terhadap nilai baku mutunya berdasarkan Peraturan Pemerintah (PP) Nomor 82 Tahun 2001. Indeks ini menyederhanakan data kualitas air dengan istilah baik, tercemar ringan, tercemar sedang, dan tercemar berat. Evaluasi terhadap nilai IP ditentukan berdasarkan Keputusan Menteri Negara Lingkungan Hidup Nomor 115 Tahun 2003 (Tabel 3).

Tabel 2. Paramater kualitas air yang diuji

\begin{tabular}{|c|c|c|c|}
\hline No. & Parameter & Alat dan metode & Baku mutu \\
\hline \multicolumn{4}{|c|}{ Parameter Fisika } \\
\hline 1 & Kekeruhan (NTU) & Turbidimeter (analisis in situ) & \\
\hline 2 & $\mathrm{TSS}(\mathrm{mg} / \mathrm{L})$ & Metode gravimetri & 50 \\
\hline 3 & Suhu $\left({ }^{\circ} \mathrm{C}\right)$ & Termometer (analisis in situ) & Deviasi 3 \\
\hline \multicolumn{4}{|c|}{ Parameter Kimia } \\
\hline 1 & $\mathrm{pH}$ & $\mathrm{pH}$ meter (analisis in situ) & $6-9$ \\
\hline 2 & $\mathrm{COD}(\mathrm{mg} / \mathrm{L}$ & Metode refluks (SNI 6989-73-2009) & 25 \\
\hline 3 & $\mathrm{DO}(\mathrm{mg} / \mathrm{L}$ & Metode Winkler & $>4$ \\
\hline 4 & BOD5 (mg/L) & Metode Winkler dan inkubasi & 3 \\
\hline 5 & Nitrat $(\mathrm{mg} / \mathrm{L})$ & Metode spektrofotometer & 10 \\
\hline 6 & Nitrit (mg/L) & Metode spektrofotometer & 0,06 \\
\hline 7 & Fosfat (mg/L) & Metode spektrofotometer & 0,2 \\
\hline 8 & Amonia $(\mathrm{mg} / \mathrm{L})$ & Metode spektrofotometer & $(-)$ \\
\hline \multicolumn{4}{|c|}{ Parameter Biologi } \\
\hline 1 & Total Coliform (MPN/100 mL) & Metode APHA & 5000 \\
\hline
\end{tabular}


Tabel 3. Status mutu air berdasarkan Indeks Pencemaran

\begin{tabular}{ll}
\hline \multicolumn{1}{c}{ Nilai IP } & \multicolumn{1}{c}{ Mutu air } \\
\hline $0 \leq \mathrm{IP} \leq 1,0$ & baik (sesuai baku mutu) \\
$1,0<\mathrm{IP} \leq 5,0$ & tercemar ringan \\
$5,0<\mathrm{IP} \leq 10$ & tercemar sedang \\
IP $>10$ & tercemar berat \\
\hline
\end{tabular}

\section{Hasil}

Gambar 2 menunjukkan hasil analisis laboratorium untuk masing-masing parameter kualitas air di lima titik sampling dari hulu hingga ke hilir. Hasil analisis parameter kualitas air berbeda untuk setiap titik sampling tergantung pada pemanfaatan lahan di sekitar aliran sungai. Beban pencemar bersifat NPS sehingga kemungkinan ini dapat menjelaskan jumlah bahan pencemar yang masuk ke badan air, sehingga memengaruhi nilai masing-masing parameter di setiap titik sampling.

Suhu air Sungai Percut dari hulu ke hilir meningkat. Suhu tertinggi diperoleh di bagian hilir sungai, yaitu di Jembatan Paluh Merbau. Kekeruhan tertinggi diperoleh di Titik 3, yaitu Jembatan Amplas. Titik ini berada di dalam kawasan industri dan pengambilan sampel air dilakukan dekat dengan area industri. Nilai TSS tertinggi di
Sungai Percut diperoleh di Titik 2, yaitu 4 $\mathrm{mg} / \mathrm{L}$, namun tidak melebihi nilai baku mutu sebesar $50 \mathrm{mg} / \mathrm{L}$. Kisaran $\mathrm{pH}$ air Sungai Percut yaitu 6,25-7,40 sesuai dengan baku mutu kualitas perairan kelas II menurut PP Nomor 82 Tahun 2001.

Nilai COD di Titik 1, 2, dan 5 berada pada kisaran yang sudah melebihi baku mutu menurut PP Nomor 82 Tahun 2001. Konsentrasi nitrit yang ditemukan di Titik 3 Jembatan Amplas, yaitu 0,158 mg/L, sudah melebihi nilai baku mutu menurut PP Nomor 82 Tahun 2001 kelas II. Konsentrasi fosfat di Titik 5, yaitu sebesar $0,3455 \mathrm{mg} / \mathrm{L}$, sudah melebihi baku mutu perairan kelas II menurut PP Nomor 82 Tahun 2001.

Analisis kandungan total coliform di Sungai Percut menghasilkan kandungan tertinggi yang ditemukan di Titik 2, yaitu sebesar 16.000 MPN/100 mL, sedangkan kandungan terendah ditemukan di Titik 1 sebesar $470 \mathrm{MPN} / 100 \mathrm{~mL}$. 

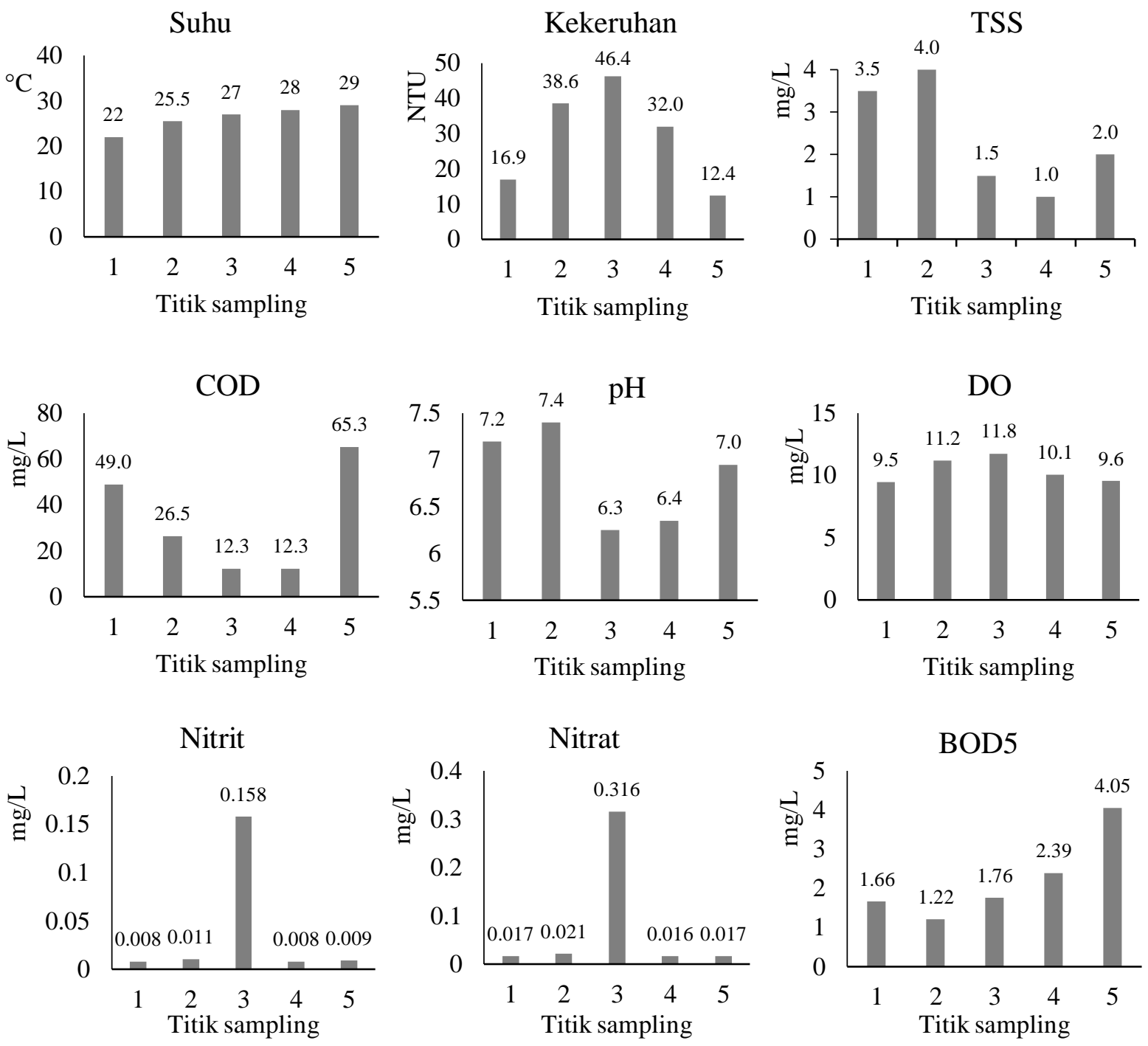

Amonia
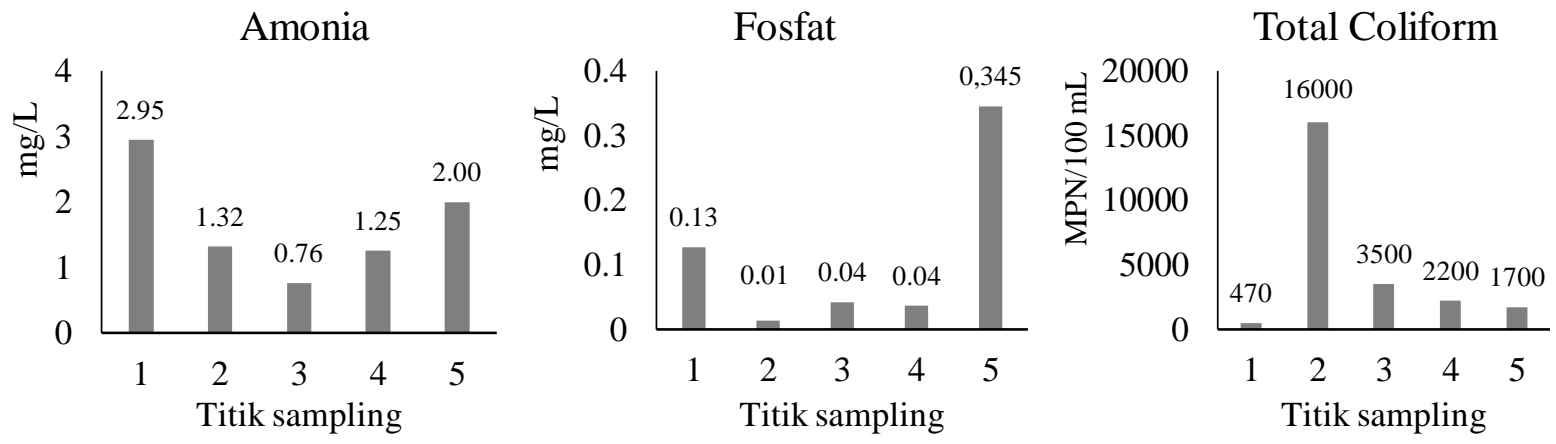

Gambar 2. Nilai parameter fisika, kimia, dan biologi sampel air Sungai Percut

Tabel 4 menunjukkan status mutu air Sungai Percut di kelima titik sampling dari hulu hingga ke hilir, yaitu tercemar ringan dengan nilai IP tertinggi di Titik 1 sebesar 3,55 , sedangkan nilai IP terendah di Titik 4 sebesar 2,21. 
Tabel 4. Status mutu kualitas air

\begin{tabular}{lcc}
\hline \multicolumn{1}{c}{ Titik sampling } & $\begin{array}{c}\text { Indeks } \\
\text { Pencemaran }\end{array}$ & Status mutu air \\
\hline Titik 1 Jembatan Bukum & 3,55 & Tercemar ringan \\
Titik 2 Jembatan Sarilabajahe & 2,66 & Tercemar ringan \\
Titik 3 Jembatan Amplas & 2,49 & Tercemar ringan \\
Titik 4 Jembatan Tembung & 2,21 & Tercemar ringan \\
Titik 5 Jembatan Paluh Merbau & 3,05 & Tercemar ringan \\
\hline
\end{tabular}

\section{Pembahasan}

Sumber utama pencemaran air sungai berasal dari limbah domestik (permukiman), limbah hewan, limbah pertanian (pestisida dan pupuk), erosi tanah, dan limbah industri (Bhardwaj et al., 2010). Pencemaran Sungai Percut terutama disebabkan oleh limbah organik, terlihat dari nilai BOD yang semakin tinggi dari hulu ke hilir.

Meskipun terjadi peningkatan suhu air Sungai Percut dari hulu ke hilir, namun secara umum, suhu air Sungai Percut masih dalam kisaran normal karena memiliki deviasi 3 dari keadaan temperatur alamiah di lingkungan setempat (Puspitasari et al., 2017) yaitu temperatur alamiah untuk pertumbuhan fitoplankton pada suhu 20$30^{\circ} \mathrm{C}$ (Effendi, 2003). Suhu memengaruhi kemampuan air dalam menyerap oksigen dari udara (Effendi \& Wardiatno, 2015). Kemampuan ini berpengaruh terhadap kemampuan dekomposisi bahan organik oleh mikroba.

Kekeruhan tertinggi yang diperoleh di Titik 3, yaitu Jembatan Amplas, kemungkinan berkaitan dengan lokasi titik ini yang berada di kawasan industri. Air buangan dan limbah industri yang dihasilkan diduga menyebabkan nilai kekeruhan yang tinggi di titik ini. Nilai kekeruhan untuk air minum sebesar 0,5 NTU (Said et al., 2004), maka Sungai Percut tidak layak sebagai sumber air minum. Longsor dan hujan pada saat pengambilan sampel mempengaruhi kondisi status mutu air Sungai Percut di Titik 1.

TSS dan kekeruhan memengaruhi jumlah cahaya yang masuk ke dalam perairan (Ali et al., 2013). Nilai TSS dan kekeruhan dipengaruhi oleh keberadaan bahan tersuspensi, yaitu padatan, lumpur, pasir halus, bahan organik dan anorganik, serta jasad-jasad renik (Effendi \& Wardiatno, 2015) yang mengalir ke sungai akibat longsor dan aktivitas antropogenik yang tinggi. Nilai TSS tertinggi di Sungai Percut diperoleh di Titik 2 sebesar $4 \mathrm{mg} / \mathrm{L}$, tetapi tidak melebihi nilai baku mutu 50 $\mathrm{mg} / \mathrm{L}$. Aktivitas manusia yang tinggi di titik ini diakibatkan oleh pemanfaatan Sungai Percut sebagai area wisata yaitu tempat pemandian Sungai Sibiru-biru. Kondisi Sungai Percut dari segi parameter fisika (suhu, TSS, dan kekeruhan) secara umum baik atau normal karena tidak melebihi baku mutu kualitas air menurut PP Nomor 82 Tahun 2001.

$\mathrm{pH}$ air Sungai Percut yang berkisar 6,25-7,40 sudah memenuhi baku mutu kualitas perairan kelas II menurut PP Nomor 82 Tahun 2001. Kondisi pH juga memengaruhi nilai BOD5 dan COD (Himawan et al., 2012) serta fosfat, nitrogen, dan nutrien yang lain (Caicedo et $a l .$, 2000). Nilai baku mutu COD menurut PP Nomor 82 Tahun 2001 yaitu 25 mg/L. Nilai COD yang melebihi baku mutu di titik sampling 1, 2, dan 5 kemungkinan disebabkan oleh material longsor yang masuk ke sungai berupa serasah yang 
membusuk, pembuangan limbah domestik dari permukiman, dan aktivitas wisata serta pertanian.

Menurut Lohani dan Hee (1983), konsentrasi oksigen terlarut (DO) minimum adalah $4 \mathrm{mg} / \mathrm{L}$ untuk perairan kelas II, yaitu untuk kegiatan perikanan dan pertanian. Konsentrasi DO yang berkisar 9,45-11,75 $\mathrm{mg} / \mathrm{L}$ di semua titik sampling Sungai Percut masih memenuhi baku mutu. Nilai parameter BOD5 tertinggi diperoleh di Titik 5 , yaitu $4,05 \mathrm{mg} / \mathrm{L}$ yang sudah melebihi nilai baku mutu menurut PP Nomor 82 Tahun 2001 sebesar $3 \mathrm{mg} / \mathrm{L}$. Nilai parameter BOD5 yang semakin tinggi ke arah hilir berarti beban pencemar organik yang masuk ke dalam sungai semakin meningkat (Marlena, 2012).

Menurut PP Nomor 82 Tahun 2001 kandungan amonia untuk perairan kelas I harus di bawah $0,5 \mathrm{mg} / \mathrm{l}$. Kadar amonia di semua titik sampling melebihi standar baku mutu untuk perairan kelas I, maka air Sungai Percut telah tercemar akibat proses amonifikasi yang berasal dari penguraian bahan organik oleh mikroba (Suwari, 2010). Kadar amonia yang tinggi juga mengindikasikan keberadaan limbah domestik dari permukiman (Hibban et al., 2016), industri, dan aktivitas pertanian yang masuk ke dalam air. Selain itu, amonia yang terdapat dalam mineral juga dapat masuk ke badan air melalui erosi tanah (SAKA, 2019).

Menurut PP Nomor 82 Tahun 2001, konsentrasi nitrat untuk perairan kelas II, yaitu untuk rekreasi, perikanan, dan pertanian harus di bawah $10 \mathrm{mg} / \mathrm{L}$. Konsentrasi nitrat di setiap titik penelitian sudah memenuhi standar kualitas air kelas II. Nitrat yang tinggi akan memicu proses eutrofikasi, sehingga oksigen berkurang dalam perairan (Rumanti et al., 2014). Nitrit dalam badan air berasal dari limbah industri dan limbah domestik.

Konsentrasi nitrit yang melebihi nilai baku mutu menurut PP Nomor 82 Tahun 2001 kelas II ditemukan di Titik 3 Jembatan Amplas, yaitu $0,158 \mathrm{mg} / \mathrm{L}$. Konsentrasi nitrit yang tinggi ini diduga berasal dari pembuangan limbah domestik dari permu- kiman dan industri tekstil (zat pewarna), seluloid, industri logam, karet remah, dan produk makanan ke sungai. Di Titik 3, konsentrasi amonia ditemukan paling rendah, sedangkan konsentrasi nitritnya tinggi. Hal ini kemungkinan terkait dengan proses nitrifikasi, yaitu oksidasi amonia menjadi nitrit yang akan meningkatkan konsentrasi nitrit dan nitrat dalam perairan (Djokosetiyanto et al., 2008).

Konsentrasi fosfat di Titik 5, yaitu bagian hilir Sungai Percut sebesar 0,3455 $\mathrm{mg} / \mathrm{L}$ sudah melebihi baku mutu perairan kelas II menurut PP Nomor 82 Tahun 2001 (di bawah 0,2 $\mathrm{mg} / \mathrm{L}$ ). Konsentrasi fosfat yang tinggi di Titik 5 diduga akibat aktivitas pertanian, sawah dan tambak yang berasal dari pupuk, pakan ikan dan udang yang masuk ke aliran sungai. Namun, fosfat berperan penting untuk keberadaan dan laju pertumbuhan fitoplankton (Rumanti et al., 2014).

Hasil analisis parameter biologi menunjukkan kandungan total coliform di Sungai Percut tertinggi ditentukan di Titik 2, yaitu Jembatan Sarilabajahe sebesar 16.000 MPN/100 mL yang melebihi baku mutu menurut PP Nomor 82 Tahun 2001 sebesar 5.000 MPN/100 mL untuk perairan kelas II. Kandungan total coliform berkaitan dengan limbah organik yang berasal dari kotoran manusia dan hewan (Yudo, 2010). Titik 1 di daerah hulu merupakan kawasan yang relatif jauh dari permukiman penduduk, sehingga nilai parameter total coliform rendah. Sebaliknya, aktivitas manusia yang tinggi di kawasan wisata Sungai Sibiru-biru dan titik sampling yang berada dekat permukiman (Titik 2) yang memanfaatkan sungai untuk kegiatan mandi, mencuci, dan buang air diduga mengakibatkan kandungan total coliform meningkat.

Nilai Indeks Pencemaran (IP) tertinggi di Titik 1 Jembatan Bukum berkaitan dengan longsor yang terjadi sebulan sebelum pengambilan sampel dan kondisi hujan pada saat pengambilan sampel, sedangkan nilai terendah di Titik 4 Jembatan Tembung kemungkinan disebabkan pemanfaatan lahan yang tidak beragam 
dan didominasi permukiman. Keragaman pemanfaatan lahan memengaruhi jumlah beban pencemar yang dihasilkan. Penggunaan Indeks Pencemaran lebih memudahkan untuk mengevaluasi suatu perairan secara menyeluruh (Said et al., 2004) dan lebih objektif karena penyebab nilai indeks yang tinggi akibat beban pencemar yang tinggi dapat diketahui, sehingga pola pengelolaan yang tepat mudah ditentukan.

\section{Kondisi Pemanfaatan Lahan Jembatan Bukum}

Jembatan Bukum atau Titik 1 mewakili kawasan hulu Sungai Percut. Bagian hulu DAS Percut mempunyai tipe tutupan lahan berupa hutan, semak belukar, lahan pertanian, dan sawah. Kondisi kualitas air di titik ini tercemar ringan. Gambar 2 memperlihatkan bahwa nilai parameter COD cukup tinggi, bahkan sudah melebihi baku mutu. Menurut Yudo (2010), konsentrasi COD yang semakin tinggi mengindikasikan tingkat pencemaran yang semakin besar di suatu perairan. Pencemaran di daerah hulu kemungkinan disebabkan oleh longsor yang terjadi di Sibolangit pada bulan April 2019 dan curah hujan yang tinggi pada saat pengambilan sampel membawa material longsor ke aliran sungai. Kekeruhan di Titik 1 yang bernilai 16,9 NTU dapat dikatakan tinggi untuk daerah hulu. Longsor yang mengandung material erosi berupa lumpur dan serasah yang membusuk (Effendi \& Wardiatno, 2015) terbawa masuk ke aliran sungai akibat hujan. Selain itu, limbah dari pertanian dan sawah juga menyumbang nilai parameter COD dan kekeruhan yang tinggi di titik ini.

\section{Jembatan Sarilabajahe}

Pemanfaatan lahan di kawasan ini terutama sebagai lahan pertanian dan kegiatan wisata berupa pemandian alam Sungai Sibiru-biru. Jumlah permukiman sedikit, tetapi masyarakat yang menetap di pinggir dan sekitar aliran sungai memanfaatkan sungai sebagai tempat pembuangan limbah domestik. Aktivitas wisata Sungai Sibiru-biru meningkatkan nilai $\mathrm{pH}, \mathrm{COD}$, dan amonia di Sungai Percut. Nilai pH meningkat akibat aktivitas mandi, mencuci, buang air, dan sisa makanan yang dibuang ke sungai (Effendi \& Wardiatno, 2015). COD menggambarkan total organik yang ada dalam perairan (Atima, 2015). COD berasal limpasan pertanian dan aktivitas manusia yang bermukim di sekitar aliran sungai. Amonia berasal dari senyawa nitrogen yang berubah menjadi $\mathrm{NH}_{4}$ dalam $\mathrm{pH}$ rendah yang berasal dari kotoran manusia (Muara et al., 2019). Nilai total coliform di titik ini yang melebihi nilai baku mutu, yaitu sebesar $16.000 \mathrm{MPN} / 100 \mathrm{~mL}$, kemungkinan besar berasal dari bakteri coliform dalam limbah domestik kotoran manusia yang masuk ke dalam air sungai (Samudro et al., 2012).

\section{Jembatan Amplas}

Pemanfaatan DAS di sekitar Jembatan Amplas didominasi oleh kegiatan pertanian, namun titik sampling berada di dekat kawasan industri Medan-Amplas. Kondisi ini memengaruhi nilai parameter kualitas air, yaitu nitrat, nitrit, amonia, dan fosfat. Menurut Afed Ullah et al. (2018), konsentrasi nitrat, nitrit, dan fosfat yang tinggi disebabkan oleh pemupukan dan pengolahan tanah (pembajakan) yang berlebihan, sehingga merusak struktur tanah. Konsentrasi nitrat, nitrit, dan amonia juga dipengaruhi oleh daerah permukiman dan industri di dekatnya. Ada kemungkinan industri di sekitarnya belum melakukan pengelolaan limbah secara tepat sebelum dibuang ke aliran sungai.

\section{Jembatan Tembung}

Tutupan lahan di area Titik 4 berupa permukiman, perkebunan, dan pertanian, namun pemanfaatan lahan di sekitar Jembatan Tembung didominasi oleh permukiman. Daerah ini merupakan kawasan padat penduduk dan daerah perkotaan. Pembuangan limbah domestik yang berasal dari permukiman ke aliran sungai sangat memengaruhi kondisi kualitas air sungai di titik ini. Masyarakat di sekitar 
Sungai Percut memanfaatkan sungai sebagai MCK dan membuang limbah organik dan anorganik, sungai ini juga dijadikan sebagai tempat pembuangan sampah.

\section{Jembatan Paluh Merbau}

Jembatan Paluh Merbau merupakan daerah hilir Sungai Percut. Kualitas air di titik ini dipengaruhi oleh beban pencemaran yang terakumulasi dari hulu. Penggunaan lahan beragam di daerah hilir, yaitu berupa hutan bakau, belukar, rawa, permukiman, sawah, perkebunan, dan tambak. Kawasan permukiman mendominasi daerah hilir dan titik pengambilan sampel mewakili kawasan tambak yang dekat dengan muara Sungai Percut. Konsentrasi fosfat yang tinggi di kawasan ini menggambarkan tingkat nutrisi dan eutrofikasi di sungai (Mahyudin et al., 2015). Aktivitas antropogenik berupa pemanfaatan lahan menjadi tambak dan sawah (Suwari, 2010) di sekitar Titik 5 menghasilkan beban pencemar yang berasal dari pemupukan dan pemberian pakan yang berlebihan. Hal ini dapat meningkatkan konsentrasi fosfat, amonia, nitrat, dan nitrit yang berpotensi menghilangkan keanekaragaman hayati (Syawal et al., 2016).

\section{Kesimpulan}

Status mutu air Sungai Percut berdasarkan metode IP adalah tercemar ringan, meskipun beberapa parameter kimia perairan di bagian hilir sungai jauh melebihi baku mutu. Limbah organik merupakan limbah yang dominan mencemari sungai Percut. Pencemaran limbah organik yang terjadi di Sungai Percut disebabkan oleh aktivitas antropogenik berupa pemanfaatan lahan pertanian dan permukiman. Perubahan fungsi dan pemanfaatan lahan harus dikontrol sesuai dengan prinsip pengelolaan lingkungan, yaitu konservasi, pendayagunaan, pengendalian, dan tidak melebihi daya tampung dan daya dukung lingkungan. Manajemen tata kelola lahan dan pemantauan, pengawasan serta pengelolaan limbah menjadi solusi agar status mutu air Sungai Percut sesuai dengan peruntukannya.

\section{Ucapan Terima Kasih}

Penulis mengucapkan terima kasih kepada Balai Wilayah Sungai (BWS) Sumatera II dan Balai Pemantapan Kawasan Hutan (BPKH) Wilayah I Medan yang telah memberikan dukungan data untuk penelitian ini.

\section{Referensi}

Afed Ullah K, Jiang J, Wang P. 2018. Land use impacts on surface water quality by statistical approaches. Global Journal of Environmental Science and Management 4: 231-250

Ali A, Soemarno, Purnomo M. 2013. Kajian kualitas air dan status mutu air sungai Metro di Kecamatan Sukun kota Malang. Bumi Lestari Journal of Environment 13:265-274

Atima W. 2015. BOD dan COD Sebagai Parameter Pencemaran Air dan Baku Mutu Air Limbah. Biosel: Biology Science and Education 4: 83-93

Bhardwaj V, Singh D Sen, Singh AK. 2010. Water quality of the Chhoti Gandak River using principal component analysis, Ganga Plain, India. Journal of earth system science 119: 117-127

Caicedo JR, Van Der Steen NP, Arce O, Gijzen HJ. 2000. Effect of total ammonia nitrogen concentration and $\mathrm{pH}$ on growth rates of duckweed (Spirodela polyrrhiza). Water Research 34: 38293835 . DOI: 10.1016/S00431354(00)00128-7

Djokosetiyanto D, Sunarma A, Widanarni. 2008. Perubahan Ammonia (NH3-N), Nitrit (NO2-N) dan Nitrat (NO3-N) pada Media Pemeliharaan Ikan Nila Merah (Oreochromis Sp.) di dalam Sistem Resirkulasi. Jurnal Akuakultur Indonesia 7: 19-24

du Plessis A, Harmse T, Ahmed F. 2014. 
Quantifying and predicting the water quality associated with land cover change: a case study of the Blesbok Spruit Catchment, South Africa. Water 6: 2946-2968

Effendi H. 2003. Telaah Kualitas Air bagi Pengelolaan Sumber Daya dan Lingkungan Perairan. Kanisius: Yogyakarta

Effendi H, Wardiatno Y. 2015. Water quality status of Ciambulawung River, Banten Province, based on pollution index and NSF-WQI. Procedia Environmental Sciences 24: 228-237

EPA U. 2018. Polluted Runoff: Nonpoint Source (NPS) Pollution. An official website of the United States government. Tanggal akses 10 April 2020. https://www.epa.gov/nps/basicinformation-about-nonpoint-source-npspollution

Hibban M, Rezagama A, Purwono. 2016. Studi Penurunan Konsentrasi Amonia dalam Limbah Cair Domestik dengan Teknologi Biofilter Aerobmedia Tubular Plastik pada Awal Pengolahan. Jurnal Teknik Lingkungan 5: 1-9

Himawan D.S, Syafrudin GS. 2012. Studi Pengaruh Volumetric Loading Rate dan Upflow Velocity terhadap Penurunan Parameter BOD,COD,TSS, dan Nitrat dalam Limbah Cair Domestik Artificial Menggunakan Reaktor UASB. Jurnal Teknik Lingkungan 1: 1-12

Kep. MENLH NO 115 Tahun 2003. Surat Keputusan Menteri Negara Lingkungan Hidup Nomor 115 Tahun 2003 tentang Pedoman Penentuan Status Mutu Air

Lohani BN, Hee KB. 1983. A CCDP model for water quality management in the Hsintien River in Taiwan. International Journal of Water Resources Development 1: 91-114

Mahyudin M, Soemarno S, Prayogo TB. 2015. Analisis kualitas air dan strategi pengendalian pencemaran air Sungai Metro di Kota Kepanjen Kabupaten Malang. Indonesian Journal of Environment and Sustainable Development 6: 105-114
Marlena B. 2012. Kajian Pengelolaan Sub DAS Garang Hulu terhadap Kualitas Air Sungai. Tesis. Universitas Diponegoro: Semarang

Muara DI, Banyuasin S, Selatan S, Banyuasin OF, Estuary R, Sumatera S. 2019. Kondisi nitrat, nitrit, amonia, fosfat dan bod di muara sungai banyuasin, sumatera selatan. Jurnal Ilmu dan Teknologi Kelautan Tropis 11: 65-74. DOI: http://dx.doi.org/10.29244/jitkt. v11i1.18861

Peraturan Pemerintah (PP) RI Nomor 82 Tahun 2001 tentang Pengelolaan Kualitas Air dan Pengendalian Pencemaran Air.

Priyambada IB, Suprapto RPE. 2008. Analisa Pengaruh Perbedaan Fungsi Tata Guna Lahan Terhadap Beban Cemaran BOD Sungai (Studi Kasus: Sungai Serayu-Jawa Tengah). Jurnal Presipitasi: Media Komunikasi dan Pengembangan Teknik Lingkungan 5: 55-62

Puspitasari RL, Elfidasari D, Aulunia R, Ariani F. 2017. Studi kualitas air sungai Ciliwung berdasarkan bakteri indikator pencemaran pasca kegiatan bersih Ciliwung 2015. Jurnal Al-Azhar Indonesia Seri Sains dan Teknologi 3: 156-162

Rumanti M, S.Rudiyanti, M.N.Suparjo. 2014. Hubungan Antara Kandungan Nitrat Dan Fosfat Dengan Kelimpahan Fitoplankton Di Sungai Bremi Kabupaten Pekalongan. Management of Aquatic Resources Journal 3:168-176

Said A, Stevens DK, Sehlke G. 2004. An innovative index for evaluating water quality in streams. Environmental management 34: 406-414

SAKA. 2019. Kadar Amonia dalam Perairan. Tanggal akses: 14 April 2020 http://www.saka.co.id/newsdetail/kadaramonia-dalam-perairan

Samudro S, Agustiningsih D, Sasongko SB. 2012. Analisis Kualitas Air dan Strategi Pengendalian Pencemaran Air Sungai Blukar Kabupaten Kendal. Jurnal Presipitasi 9: 64-71 
Saraswati SP, Sunyoto S, Kironoto BA, Hadisusanto S. 2014. Kajian Bentuk Dan Sensitivitas Rumus Indeks Pi, Storet, Ccme Untuk Penentuan Status Mutu Perairan Sungai Tropis Di Indonesia (Assessment of the Forms and Sensitivity of the Index Formula Pi, Storet, Ccme for the Determination of Water Quality Status). Jurnal Manusia dan Lingkungan 21: 129-142

Sholikhah I, Taufik M, Sudjatmiko K. 2017. Study of the Recharge Area on Water Basin Soil with Remote Sensing Method Using Satellite Imagery Landsat 7 ETM+ and Geographic Information Systems (GIS)(Case Study: Pasuruan District).
IPTEK The Journal for Technology and Science 28: 68-73

Suwari. 2010. Model Pengendalian Pencemaran Air pada Wilayah Kali Surabaya. Disertasi: Institut Pertanian Bogor

Syawal MS, Wardiatno Y, Hariyadi S. 2016. Pengaruh Aktivitas Antropogenik Terhadap Kualitas Air, Sedimen dan Moluska di Danau Maninjau, Sumatera Barat. Jurnal Biologi Tropis 16: 1-14

Yudo S. 2010. Kondisi Kualitas Air Sungai Ciliwung Di Wilayah DKI Jakarta Ditinjau Dari Paramater Organik, Amoniak, Fosfat, Deterjen Dan Bakteri Coli. Jurnal Air Indonesia 6: 34-42 